\title{
Quality of life and depression in adults with repaired complex cyanotic congenital heart disease in the Czech Republic
}

\author{
Jana Rubáčková Popelováa,b, Renata Živnáa, Markéta Tomkováa , Jakub Tomek \\ a Department of Cardiac Surgery, Hospital Na Homolce, Prague, Czech Republic \\ ${ }^{b}$ Pediatric Heart Centre, Faculty Hospital Motol, Prague, Czech Republic
}

\section{ARTICLE INFO}

Article history:

Received: 4. 10. 2018

Received in revised form:

13. 11.2018

Accepted: 17. 11. 2018

Available online: 13. 2. 2019

Klíčová slova:

Deprese

Dospělí

Dotazník SF-36

Komplexní vrozené srdeční vady

Kvalita života

\section{SOUHRN}

Úvod: Zajištění dobré kvality života je důležitý cíl léčby pacientů s komplexní cyanotickou vrozenou srdeční vadou (VSV). V literatuře však neexistuje shoda o kvalitě života těchto pacientů. Cílem naší studie bylo zhodnocení kvality života a výskytu depresí u dospělých s pưvodně komplexní cyanotickou VSV v dlouhodobém odstupu od operace.

Metody: Vyšetřili jsme celkem 212 dospělých po operaci komplexní cyanotické VSV a 86 zdravých kontrol pomocí dotazníku hodnocení kvality života SF-36 a Zungova dotazníku hodnocení deprese. Všichni pacienti byli dále dotázáni na subjektivní hodnocení vlivu VSV na jejich život, na fyzické aktivity, funkční třídu NYHA, vzdělání, zaměstnání, počet dětí a všichni podstoupili echokardiografické vyšetření. Výsledky byly srovnány se skupinou 32 neoperovaných pacientů s komplexní cyanotickou VSV, jejichž výsledky jsme publikovali $\checkmark$ minulosti.

Výsledky: Výskyt deprese se významně nelišil mezi skupinou operovaných s VSV a zdravými kontrolami. Těžká deprese byla u 8,5 \% pacientů s operovanou komplexní cyanotickou VSV a u 7 \% zdravých kontrol $(p=0,816)$. Mezi neoperovanými pacienty s perzistující cyanózou byl výskyt těžké deprese významně vyšší $(28,1 \%)$ oproti operovaným $(p=0,003)$. Kvalita života hodnocená pomocí dotazníku SF-36 se významně nelišila mezi pacienty s operovanými komplexními VSV a kontrolami, kromě horšího vnímání obecného zdraví, hodnocení fyzických funkcí a fyzického omezení činností.

Závěr: Pacienti s operovanou komplexní cyanotickou VSV mají v dospělosti dobrou kvalitu života, srovnatelnou s kontrolní skupinou zdravých jedinců, zatímco neoperovaní pacienti s perzistující cyanózou u komplexní VSV mají významně vyšší počet depresí.

(c) 2019, ČKS.
Keywords:

Adults

Complex congenital heart disease

Depression

Quality of life

Questionnaire SF-36

\begin{abstract}
Background: Good quality of life is an important goal in treatment of complex cyanotic congenital heart disease (CHD); however, there is a lack of consensus concerning quality of life in complex CHD patients in the literature. The aim of this study was to assess quality of life and rate of depression in adults with complex cyanotic CHD late after repair.

Method: The studied cohort consists of 212 adults with repaired complex cyanotic CHD and 86 healthy controls. Subjects filled in questionnaires evaluating quality of life (SF-36) and depression (Zung self-rating depression scale). Additional data on the influence of CHD on patient's life, physical activities, NYHA class, echocardiographic parameters, etc. were recorded. The results were compared with a previously published cohort of 32 cyanotic adults with unrepaired CHD.

Results: The rate of depression did not differ significantly between repaired CHD patients and healthy controls. Severe depression was found in $8.5 \%$ of repaired complex CHD, in $7.0 \%$ of controls $(p=0.816)$, and in $28.1 \%$ of the unrepaired CHD with persistent cyanosis $(p=0.003)$. The quality of life measured by SF-36 was not significantly different between repaired CHD and controls, except for lower general health perception, physical functioning, and physical role limitation.

Conclusion: The repaired complex cyanotic CHD patients have a good quality of life, similar to controls, while unrepaired patients have a significantly higher rate of depression.
\end{abstract}




\section{Introduction}

Advances in the surgery of neonates and children with congenital heart disease (CHD) have improved their survival so that almost $90 \%$ of children with CHD reach adult age. ${ }^{1}$ With the excellent surgical results and low mortality, the evaluation of quality of life becomes increasingly important in the rapidly growing population of adults with CHD.

The number of studies assessing quality of life in CHD is increasing steeply. Recently, a large international study of more than 4000 patients from 15 countries was published, showing generally good quality of life in CHD of different complexity with country variations. ${ }^{2}$ However, many questions remain unanswered, particularly in the case of complex CHD which were usually mixed with simple defects so far.

We are often approached by expectant parents with fetal echocardiographic finding of complex CHD. They are concerned not only about surgical solution but especially about the quality of life of their future offspring. According to many authors, the quality of life in adults with congenital heart disease is generally good, with worse results for cyanotic and complex CHD. ${ }^{2-6}$ However, the studied CHD cohorts and the methodology used are very heterogeneous and the results are often conflicting. Some studies even found improved quality of life in CHD compared to general population, ${ }^{6,7}$ while other studies reported the opposite. ${ }^{8}$ At the same time, depression in CHD patients measured by Beck Depression Inventory questionnaire was observed to predict adverse clinical outcome, ${ }^{9}$ suggesting its importance in patient risk assessment.

Our study published in Cardiology in the Young 17 years ago, was one of the first to show high incidence of depression in cyanotic complex CHD without surgical repair. ${ }^{10}$ Although the complex surgical repair eliminates cyanosis, there is no clear evidence concerning improvement of the quality of life as well. These patients could be traumatized by the surgery in childhood and subsequent cardiologic examinations. The goal of the current study is to evaluate quality of life in the cohort of the most complex cyanotic CHD who underwent surgical repair and remained without cyanosis. To compare results of unrepaired and repaired complex CHD, we used Zung self-rating depression scale score (SDS) questionnaire, ${ }^{11}$ similarly to our historical study. ${ }^{10}$ Moreover, we also used SF-36 questionnaire to compare our results with other studies.

In this work, we focus on the following questions: Does the surgical repair improve the quality of life of adult patients with complex CHD, rather than just improving survival? Is their quality of life and rate of depression comparable to general population? How important is the influence of CHD on patient's life?

\section{Materials and methods}

In our database of the tertiary referral center in Prague, Czech Republic, 2065 adult patients with CHD are systematically followed up since 2005. Within this cohort, 364 patients underwent a surgical repair of a complex cyano- tic CHD in childhood or adulthood. From this cohort 32 patients died (8.8\%). No patients with mental retardation were included. Questionnaires were sent in prepaid envelopes to the 332 patients and returned by 240 patients (response rate $72 \%$ ). The analysis was performed on 212 (64\%) fully completed questionnaires without missing answers.

Patients with the following diagnoses, all after radical repair were present: tetralogy of Fallot $(n=104)$, pulmonary atresia with biventricular repair $(n=13)$, patients with univentricular circulation after total cavo-pulmonary connection $(n=34)$, transposition of the great arteries after Mustard operation $(n=30)$, Senning operation $(n=$ 27), and Rastelli operation $(n=4)$. The control group comprised 86 healthy people of matched age and sex.

We compared the results with our historical group of 32 unrepaired adults with complex CHD and persistent cyanosis. ${ }^{10}$ This group comprised patients with functionally single ventricle, tricuspid or mitral atresia, unoperated pulmonary atresia with multiple aorto-pulmonary collaterals, tetralogy of Fallot with Blalock-Taussig shunts only, cyanotic Ebstein's anomaly, complex transposition of the great arteries, etc; all without radical repair. The details of this group are given in our previous publication. ${ }^{10}$

For patients in our contemporary cohort, the parameters obtained from medical reports were: age at surgical repair, NYHA class, echocardiographic parameters ejection fraction and global longitudinal strain of the systemic ventricle in absolute numbers and $\mathrm{N}$-terminal pro-B-type natriuretic peptide (NT-proBNP; in pmol/l with the upper normal limit $15 \mathrm{pmol} / \mathrm{l})$. The patients were sent a questionnaire with the following structure:

1. General information about contemporary state, matrimony and children, disability pension, education, employment, and physical activities, with the following scoring:

a) Education: 0: without basic education, 1: basic school, 2: training center without school leaving certificate, 3: training center with school leaving certificate, 4: secondary school with graduation, 5: university.

b) Employment: 0: no employment, 1: occasional job, 2: regular part-time job, 3: full-time job.

c) Physical activities: 1: no physical activity, 2: walks round, 3: recreational sports, 4: competitive sports.

d) Frequency of physical activities: 0: no activity, 1: once a week, 2: twice a week, 3: three times a week, 4: every second day, 5 : daily.

2. Subjective influence of CHD on patient's life was graded: 0: no influence, 1: small influence, 2: mild influence, 3: moderate influence, 4: great influence.

3. Zung's self-rating depression scale score questionnaire:11 score <50: no depression, 50-59: mild depression, 60-69: severe depression, $>70$ : very severe depression. We furthermore separately analyzed several statements from the Zung questionnaire and rated them as follows: 1: never, 2: sometimes, 3: often, 4: always. The selected statements were:

a) Q6: Sexual activities and thoughts of it bring me pleasure as before.

b) Q14: I feel hopeful about the future.

c) Q17: I feel that I am useful and needed. 
Table 1 - Characteristics of patients with repaired complex congenital heart disease and control group.

\begin{tabular}{|c|c|c|c|}
\hline & CHD $(n=212)$ & Controls $(n=86)$ & $P$-value \\
\hline Age & $35.0(27.0-42.0)$ & $38.0(31.0-43.0)$ & $p=0.1$ \\
\hline Men & $120(56.6 \%)$ & $38(44.2 \%)$ & $p=0.1$ \\
\hline Premature birth & $30(14.2 \%)$ & $9(10.5 \%)$ & $p=0.5$ \\
\hline Weight & $73.0(60.0-84.5)$ & $72.0(63.0-84.5)$ & $p=0.9$ \\
\hline Height & $172.0(166.0-178.0)$ & $173.0(167.3-182.0)$ & $p=0.2$ \\
\hline BMI & $24.7(21.7-27.8)$ & $24.2(21.0-26.3)$ & $p=0.3$ \\
\hline GLS (absolute value) & $15.0(11.0-17.0)$ & NA & NA \\
\hline $\mathrm{EF}$ & $55.0(45.0-60.0)$ & NA & NA \\
\hline NT-proBNP & $24.0(15.0-44.0)$ & NA & NA \\
\hline NYHA class & $1.8(1.5-2.0)$ & NA & NA \\
\hline NYHA 1-1.5 & $106(50.0 \%)$ & NA & NA \\
\hline NYHA 2-2.5 & $92(43.4 \%)$ & NA & NA \\
\hline NYHA 3-4 & $14(6.6 \%)$ & NA & NA \\
\hline CHD influence & $2.0(2.0-3.0)$ & NA & NA \\
\hline CHD influence 0 & $7(3.3 \%)$ & NA & NA \\
\hline CHD influence 1 & $39(18.4 \%)$ & NA & NA \\
\hline CHD influence 2 & $72(34.0 \%)$ & NA & NA \\
\hline CHD influence 3 & $57(26.9 \%)$ & NA & NA \\
\hline CHD influence 4 & $34(16.0 \%)$ & NA & NA \\
\hline Divorced & $15(7.1 \%)$ & $6(7.0 \%)$ & $p=1.0$ \\
\hline Education (0-5) & $4.0(2.0-4.0)$ & $4.0(4.0-5.0)$ & $p=0.0002(* * *)$ \\
\hline Higher education (4 and 5) & $123(58.0 \%)$ & $66(76.7 \%)$ & $p=0.0023(* *)$ \\
\hline Employment (0-3) & $2.0(0.0-3.0)$ & $3.0(2.0-3.0)$ & $p=0.0012(* *)$ \\
\hline Full employment (3) & $98(46.2 \%)$ & $57(66.3 \%)$ & $p=0.0021(* *)$ \\
\hline Type of physical activity (1-4) & $2.0(2.0--3.0)$ & $3.0(2.0-3.0)$ & $p<0.0001(* * *)$ \\
\hline Frequency of physical activity (0-5) & $3.0(2.0-5.0)$ & $2.0(1.0-3.0)$ & $p<0.0001(* * *)$ \\
\hline At least every other day (4-5) & $93(43.9 \%)$ & $13(15.1 \%)$ & $p<0.0001(* * *)$ \\
\hline
\end{tabular}

Data are given as median (IQR) for numeric variables, or as absolute numbers (percentage) for binary variables.

$\mathrm{BMI}$ - body mass index; CHD - congenital heart disease; EF - ejection fraction of the systemic ventricle; GLS - global longitudinal strain; NA - not applicable; NT-proBNP - N-terminal pro-B-type natriuretic peptide.

d) Q18: I feel that I lead a full life.

e) Q19: I feel it would be better for the others if I was not here.

4. Short form 36 (SF-36) questionnaire: for each of the 8 domains, scores are coded, summed, and transformed on to a scale from 0 (worst possible health state) to 100 (best possible health state).

SF1: physical functioning, SF2: role limitations due to physical functioning, SF3: bodily pain, SF4: general health, SF5: vitality, SF6: social functioning, SF7: role limitations due to emotional functioning, SF8: mental health.

The study was approved by the institutional research ethics committee. Informed consent was obtained from all patients and controls for the use of anonymous data from the questionnaires for research analysis and publication.

Values are reported as median (interquartile range, i.e., 25-75th percentile). Difference between two groups was evaluated using Fisher test for binary variables and Mann-Whitney $U$ test for all other variables. A $p$-value of less than 0.05 was considered significant $(* p<0.05$, $* * p<0.01, * * * p<0.001)$. Pairwise correlation between selected variables was computed and the $p$-values were corrected using Bonferroni correction.

\section{Results}

\section{General comparison of repaired CHD and controls}

Patients with repaired complex CHD did not significantly differ from the controls in age, gender, weight, height, $\mathrm{BMI}$, or divorce rate (Table 1). Controls achieved higher education more frequently compared to $\mathrm{CHD}(76.7 \%$ vs $58 \% ; p=0.0023)$ and more often had a full-time employment $(66.3 \%$ vs $46.2 \% ; p=0.0021)$. CHD patients performed less demanding physical activity $(p<0.0001)$; 


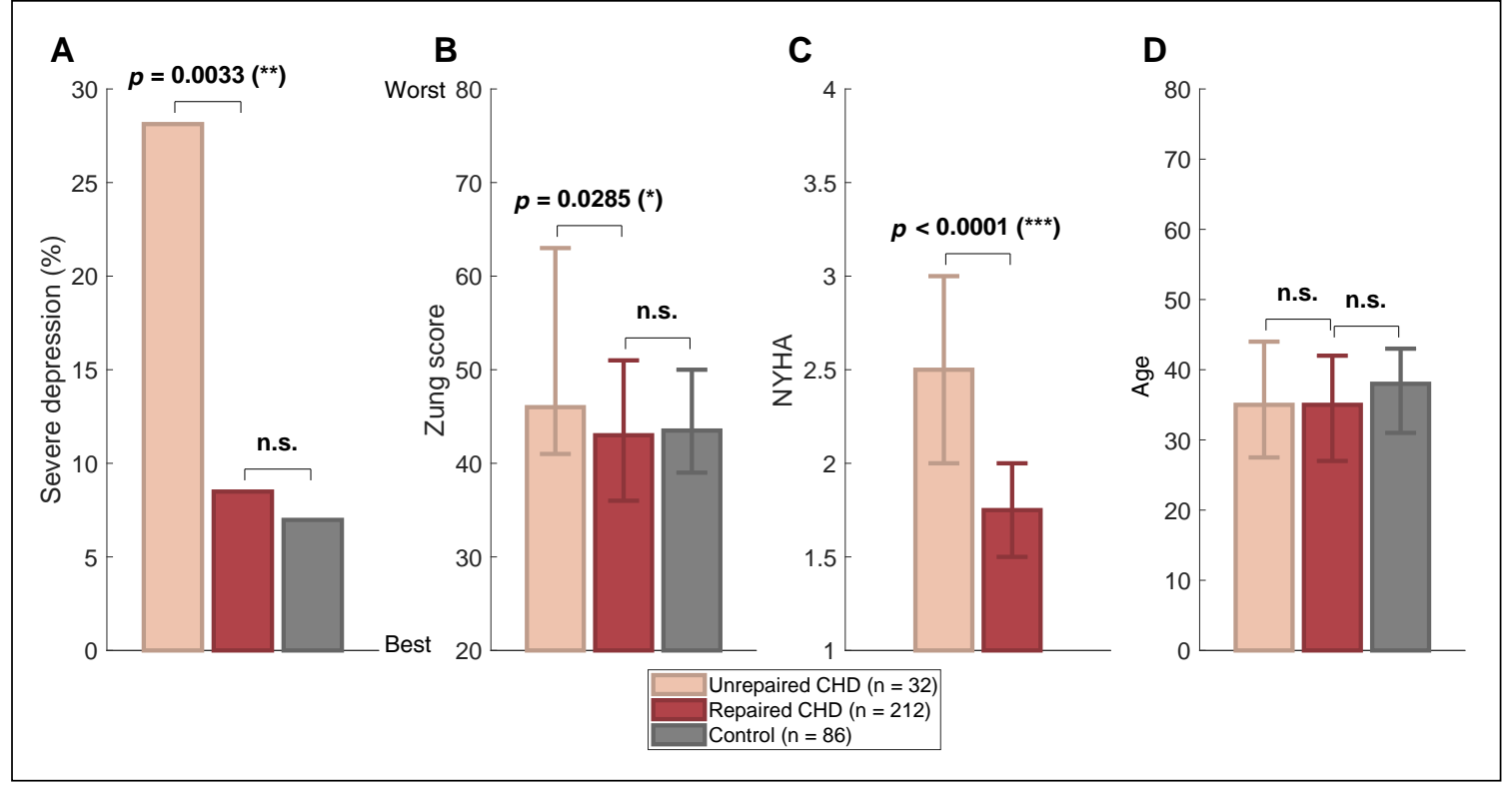

Fig. 1 - Comparison of the rate of severe depression, Zung score, NYHA class and age between repaired complex cyanotic CHD and controls. For information, the results of historical unrepaired cyanotic CHD are also shown. (A) The barplot shows the percentage of patients with severe depression (Zung score $\geq 60$ ). (B-D) The barplots show the median, with the 25th and 75th percentiles shown as errorbars. (B) Zung score in absolute value, (C) NYHA class, (D) age. n.s. - not significant, ${ }^{*} p<0.05,{ }^{* *} p<0.01, * * * p<0.001$.

Table 2 - Comparison of the Zung's self-rating depression scale score (SDS) and SF-36 in patients with repaired complex congenital heart disease (CHD) and control group.

\begin{tabular}{|c|c|c|c|}
\hline & CHD $(n=212)$ & Controls $(n=86)$ & $P$-value \\
\hline Zung SDS & $43.0(36.0-51.0)$ & $43.5(39.0-50.0)$ & $p=0.8$ \\
\hline Mild depression ( $\geq 50$ ) & $63(29.7 \%)$ & $22(25.6 \%)$ & $p=0.6$ \\
\hline Severe depression $(\geq 60)$ & $18(8.5 \%)$ & $6(7.0 \%)$ & $p=0.8$ \\
\hline Q6: sexual activities (1-4) & $3.0(2.0-4.0)$ & $3.0(3.0-4.0)$ & $p=0.5$ \\
\hline $3-4$ & $135(63.7 \%)$ & $65(75.6 \%)$ & $p=0.1$ \\
\hline Q14: future (1-4) & $3.0(2.0-4.0)$ & $3.0(2.0-4.0)$ & $p=0.3$ \\
\hline Q17: useful (1-4) & $3.0(2.0-4.0)$ & $3.0(2.5-4.0)$ & $p=0.3$ \\
\hline Q18: full life (1-4) & $3.0(2.0-4.0)$ & $3.0(3.0-4.0)$ & $p=0.5$ \\
\hline $3-4$ & $137(64.6 \%)$ & $69(80.2 \%)$ & $p=0.0086(* *)$ \\
\hline Q19: better if not here (1-4) & $1.0(1.0-1.0)$ & $1.0(1.0-1.0)$ & $p=0.1$ \\
\hline $2-4$ & $20(9.4 \%)$ & $4(4.7 \%)$ & $p=0.2$ \\
\hline SF1 physical functioning & $80.0(62.5-90.0)$ & $95.0(90.0-100.0)$ & $p<0.0001(* * *)$ \\
\hline SF2 role limitations physical & $100.0(50.0-100.0)$ & $100.0(100.0-100.0)$ & $p=0.0001(* * *)$ \\
\hline SF3 bodily pain & $100.0(81.5-100.0)$ & $100.0(81.5-100.0)$ & $p=1.0$ \\
\hline SF4 general health & $52.0(37.0-69.3)$ & $77.0(60.0-90.0)$ & $p<0.0001(* * *)$ \\
\hline SF5 vitality & $60.0(45.0-75.0)$ & $60.0(45.0-70.0)$ & $p=0.6$ \\
\hline SF6 social functioning & $87.5(62.5-100.0)$ & $92.5(75.0-100.0)$ & $p=0.1$ \\
\hline SF7 role limitations emotional & $100.0(66.6-100.0)$ & $100.0(66.6-100.0)$ & $p=0.8$ \\
\hline SF8 mental health & $76.0(64.0-84.0)$ & $74.0(64.0-84.0)$ & $p=0.2$ \\
\hline
\end{tabular}

Data are given as median (IQR) for numeric variables, or as absolute numbers (percentage) for binary variables. The selected questions were scored as follows: 1: never, 2: sometimes, 3: often, 4: all the time:

Q6: Sexual activities and thoughts of it bring me pleasure as before.

Q14: I feel hopeful about the future.

Q17: I feel that I am useful and needed.

Q18: I feel that I lead a full life.

Q19: I feel it would be better for the others if I was not here. 


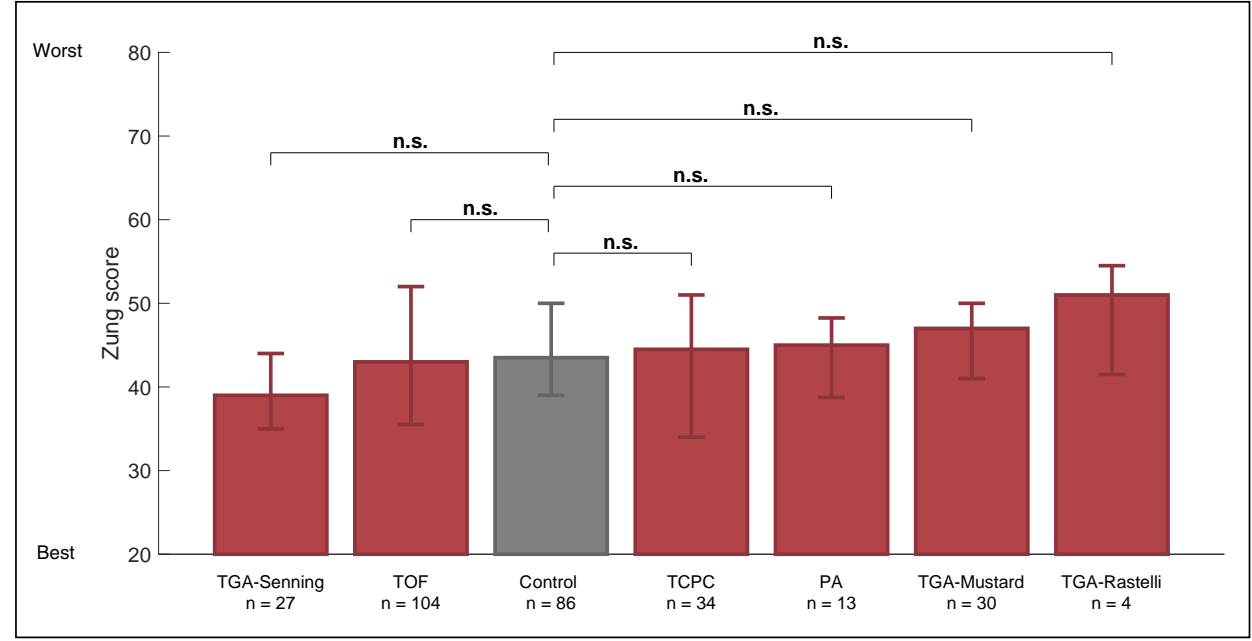

Fig. 2 - The Zung score in the individual diagnosis of complex cyanotic repaired CHD and the control group. The barplots show the median, with the 25th and 75th percentiles shown as errorbars. Diagnoses: tetralogy of Fallot (TOF), pulmonary atresia with biventricular correction (PA), total cavo-pulmonary connection (TCPC), transposition of the great arteries after Mustard operation (TGA-Mustard), Senning operation (TGA-Senning), and Rastelli operation (TGA-Rastelli). n.s. - not significant, ${ }^{*} p<0.05, * * p<0.01, * * * p<0.001$.

however, they performed it significantly more frequently $(p<0.0001)$. The majority of patients $(93.4 \%)$ were in the NYHA class $<3$. Patients with repaired complex CHD assessed the influence of the disease on their lives most frequently as mild (34\%) or moderate $(26.9 \%)$. Small or no influence was declared by $21.7 \%$. Conversely, great influence was reported by $16 \%$ of complex CHD only.

\section{Depression rate}

The depression score assessed by the Zung questionnaire did not differ significantly between repaired complex
CHD and controls: median 43.0 (36.0-51.0) vs median 43.5 (39.0-50.0), $p=0.8249$ (Table 2, Fig. 1) and there was no significant difference in the Zung score between the individual CHD diagnoses and control group (Fig. 2). Our historical group of unrepaired cyanotic CHD had significantly worse Zung score compared to contemporary repaired CHD: 46.0 (41.0-63.0) vs 43.0 (36.0-51.0), $p$ $=0.0285$ (Fig. 1). ${ }^{10}$ The rate of severe depression (Zung score $\geq 60$ ) in the group of unrepaired cyanotic CHD patients was $28.1 \%$; significantly higher compared to controls $(7.0 \%, p<0.0001)$ and repaired complex CHD

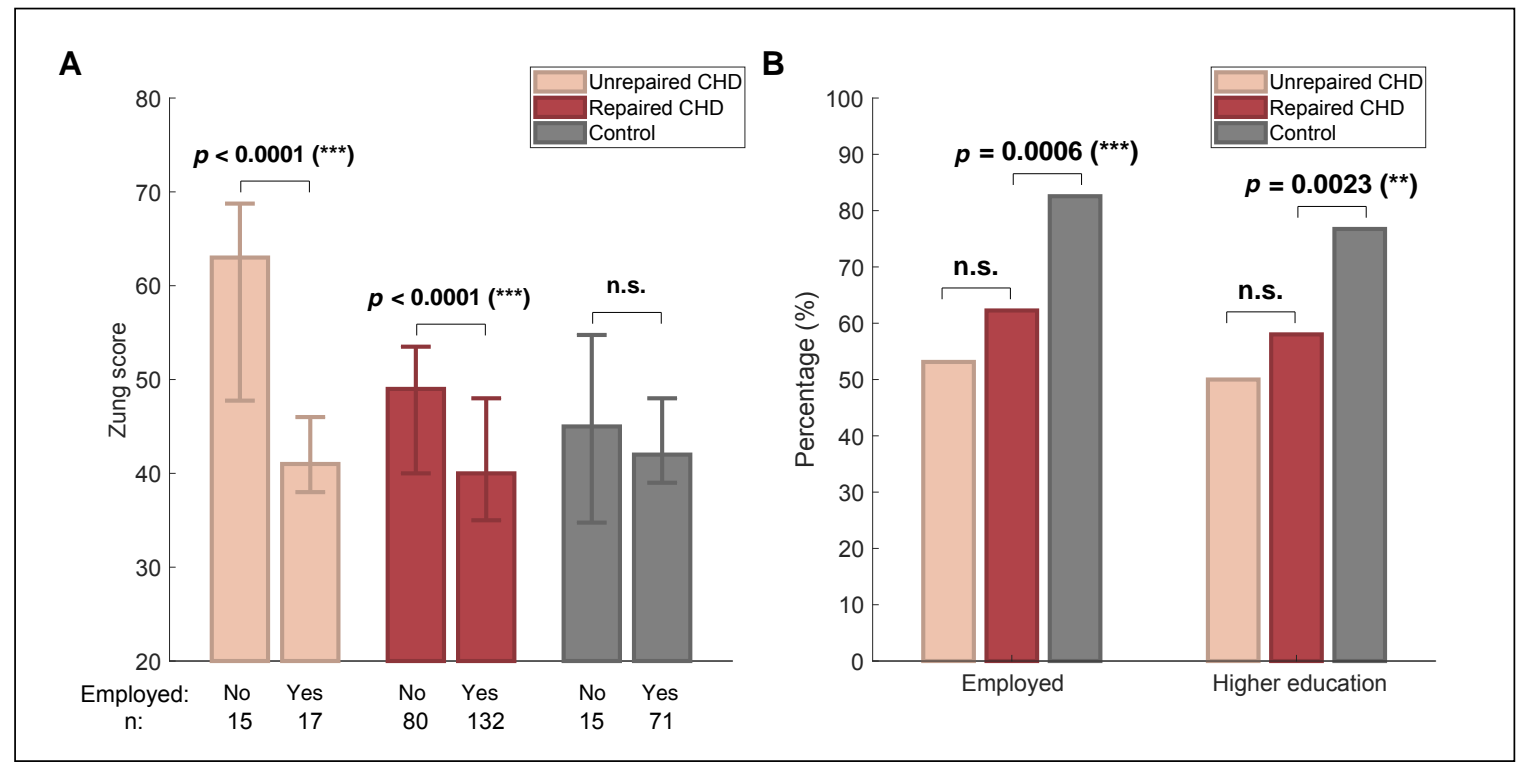

Fig. 3 - Comparison of the Zung score between repaired complex cyanotic CHD and controls, stratified by employment and education. For information, the results of historical unrepaired cyanotic CHD are also shown. (A) Distribution of Zung score in unemployed (no employment or occasional jobs only) vs employed (part-time or full-time job) in unrepaired CHD, repaired CHD, and controls. The barplots show the median, with the 25th and 75th percentiles shown as errorbars. (B) Percentage of patients with a full-time or part-time employment, and higher (university level) education. n.s. - not significant, ${ }^{*} p<0.05, * * p<0.01, * * * p<0.001$. 


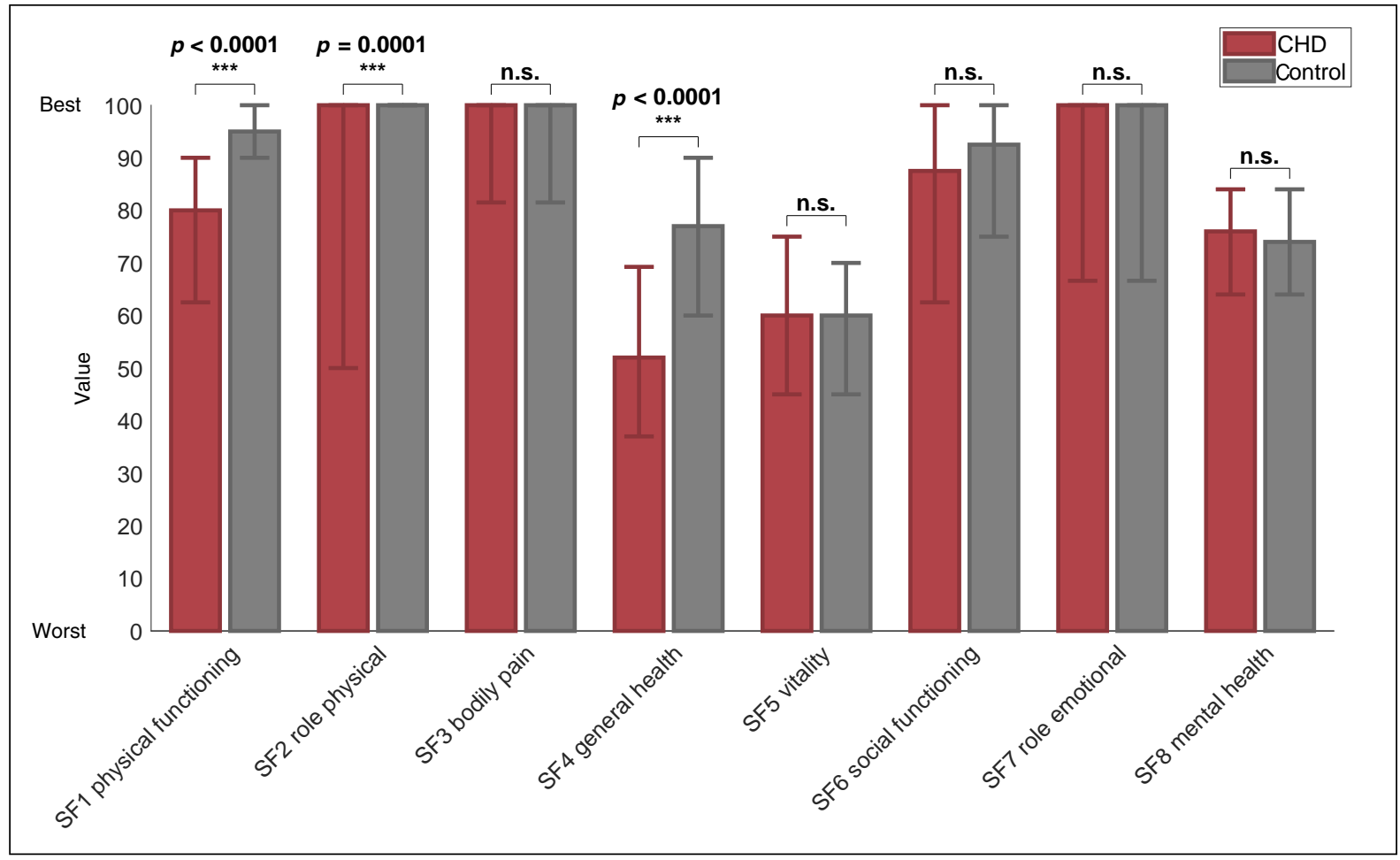

Fig. 4 - Comparison of domains of SF-36 and Zung score in repaired cyanotic CHD and the control group. The results are given as median and the error bars represent 25 th and 75 th percentiles. n.s. - not significant, ${ }^{*} p<0.05,{ }^{* *} p<0.01, * * * p<0.001$.

$(8.5 \%, p=0.003)$. The difference between controls and repaired complex CHD was not significant $(p=0.816)$. The unrepaired and repaired CHD groups did not significantly differ in age, children, employment, and education; however, they differed in NYHA class $(p<0.0001$; Fig. 1).

\section{The role of unemployment}

In the historical cohort of unrepaired complex cyanotic CHD, unemployment was an important factor associated with depression. ${ }^{10}$ Also in patients with repaired complex CHD, we observed a significantly higher Zung score in unemployed compared to employed patients $(p<0.0001$; Fig. 3). Unemployment was associated with depression most markedly in unrepaired CHD, less in repaired CHD, and not significantly in controls (Fig. 3A). The employment rate was non-significantly higher in repaired $\mathrm{CHD}$ patients compared to unrepaired CHD patients $(p=0.3$; Fig. 3B). However, it seems unlikely that unemployment could fully account for the marked difference in Zung score between the unrepaired and repaired CHD, as the difference remained significant even in unemployed patients $(p=0.0015)$.

\section{Sexual activities}

In questions concerning sexual activities, hopes for the future, and feeling useful and needed, there was no significant difference between complex repaired CHD and the control group (Table 2). The feeling of living a full life often or always was stated by $65 \%$ of CHD patients and $80 \%$ of controls $(p=0.0086)$. Sexual activities were often or always enjoyed by $64 \%$ of patients with repaired complex CHD and $76 \%$ of controls $(p=0.1)$.

\section{Suicidal thoughts}

However, $9.4 \%$ of $\mathrm{CHD}$ at least sometimes felt that it would be better for the others if they were not here; this was two-fold less common in the control group $(p=0.2)$. In our historical study with complex cyanotic CHD without repair, suicidal thoughts were admitted at least sometimes in $18.7 \%$ of unrepaired CHD cases $(p=0.1$ compared to repaired $\mathrm{CHD} ; p=0.0237$ compared to controls).

\section{Results of SF-36}

In SF-36, most domains were similar between repaired complex CHD and the control group, except for physical functioning (SF1), role limitations due to physical functioning (SF2), and general health (SF4), which were significantly lower in CHD group (Fig. 4). Conversely, there was no significant difference in bodily pain, vitality, social functioning, role limitation due to emotional functioning, and mental health.

\section{Comparison of Zung depression score and SF-36}

We did not observe a significant correlation between Zung score and age, gender, or BMI (Fig. 5). However, Zung score correlated significantly with all sections of SF-36 questionnaire, in particular with mental health ( $r$ $=-0.71 ; p<0.0001)$, vitality $(r=-0.69 ; p<0.0001)$, social functioning ( $r=-0.64 ; p<0.0001)$, and general health $(r$ $=-0.48 ; p<0.0001$ ) (Figs. 5 and 6). The correlation was negative because a high Zung score corresponds to worse mental problems, whereas the SF score is low in such a case. All depressive patients with Zung score $\geq 60$ had consistently low general health score and vitality, not exceeding the value of 60 in SF-36 questionnaire (Fig. 6). Moreover, Zung score showed a significant negative cor- 


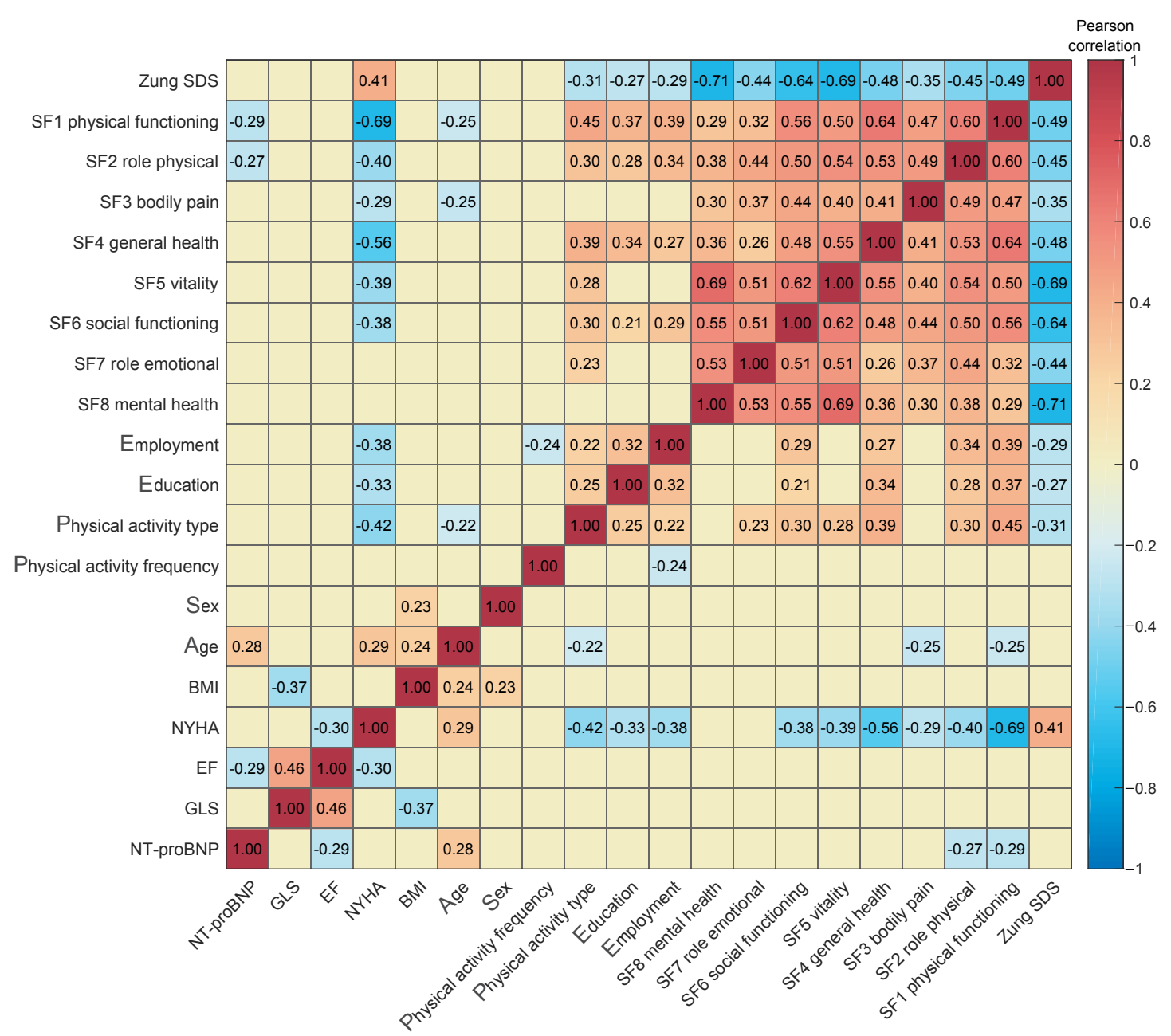

Fig. 5 - Pearson correlation of selected patient features, Zung score, and SF-36 domains. The values represent Pearson correlation coefficient for tests that were significant $(p<0.05)$ after Bonferroni multiple testing correction. Blue color represents negative correlation, while red color represents positive correlation.

relation with employment $(r=-0.29, p<0.0001)$, education $(r=-0.27, p<0.0001)$, and type of physical activity $(r=-0.31, p<0.0001)$ and positive correlation with NYHA $(r=0.41, p<0.0001)$ (Fig. 5).

NT-proBNP, one of the most prominent prognostic biomarkers in $\mathrm{CHD}$, was significantly correlated with physical functioning $(r=-0.29, p<0.0001)$, role limitations due to physical functioning $(r=-0.27, p=0.0002)$, ejection fraction $(r=-0.29, p<0.0001)$, and age $(r=0.28, p=0.0002)$, but not with NYHA class (Fig. 5).

\section{Discussion}

Our results show that while general health and physical health components of quality of life in SF-36 are decreased in patients with repaired complex CHD compared to a control group, their mental health is very similar. The two groups differed neither in Zung score, nor in the mental health values of SF-36.

These results are markedly different from our historical group of unrepaired complex cyanotic CHD patients, who showed significantly worse values of Zung score and two-fold higher rate of suicidal thoughts than our contemporary repaired CHD patients. ${ }^{10}$ The rate of severe depression (Zung score $\geq 60$ ) was significantly higher in the historical study of uncorrected cyanotic CHD (28\%) compared to the corrected cyanotic CHD (8\%) and the control group $(7 \%) .{ }^{10}$ The difference between the repaired and unrepaired CHD patients was not explainable by differences in employment, education, or age; however, the unrepaired CHD patients reported significantly worse NYHA values. This suggests importance of CHD surgical repair for both the physical and mental health.

According to the SF-36 questionnaire, our repaired complex CHD patients manifested lower physical functioning, physical role functioning, and general health than the control group. Conversely, there was no significant difference in vitality, role limitation emotional, social functioning, and mental health. Supporting the observation that the mental health of complex CHD patients is not necessarily deteriorated, Opic et al. even reported significantly better results in all CHD patients compared to control group in all SF-36 domains except general health. ${ }^{6}$ In addition, moderate and complex CHD patients manifested lower general health than patients 


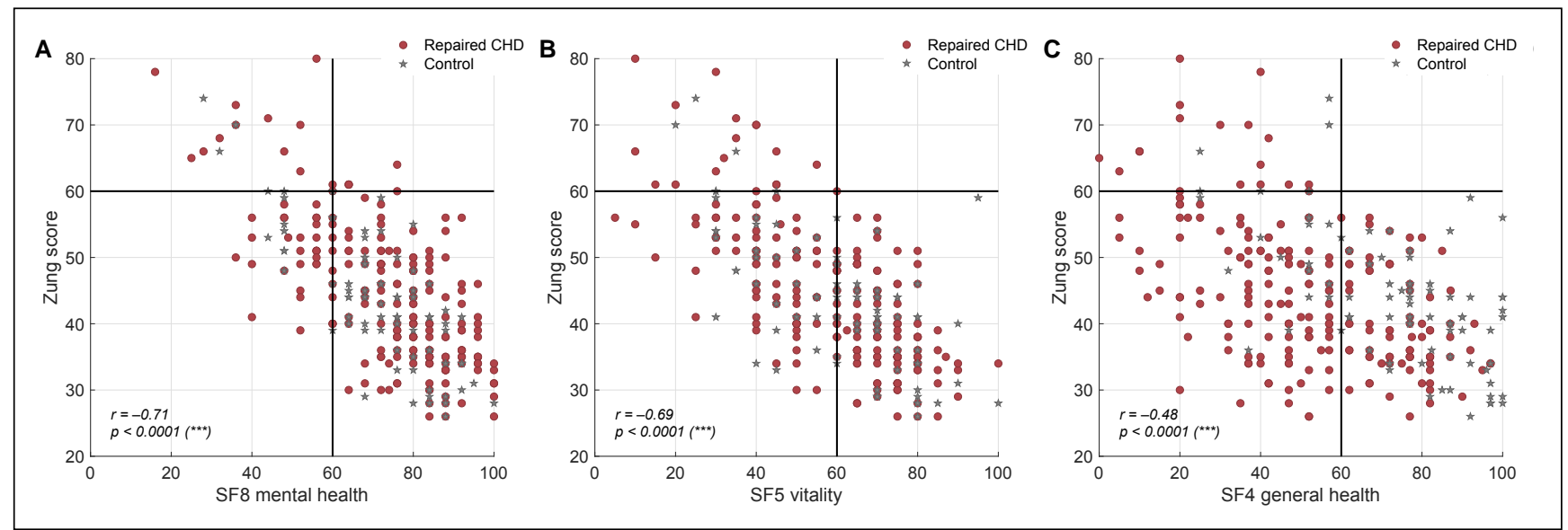

Fig. 6 - Pearson correlation between Zung score and mental health, vitality, and general health, measured by SF-36.

with simple CHD, while other SF-36 domains did not differ significantly. ${ }^{6}$ The reduced quality of life pertaining to physical functioning and general health was observed also in other studies. ${ }^{3,8,12,13}$ We might speculate that the surprisingly good mental health of complex CHD patients could be positively influenced by their regular check-ups in a specialized tertiary referral CHD center. Even without professional psychologist, the specialized cardiologist can set patients at ease concerning their treatment, significance of symptoms, and provide pregnancy counselling. The cardiologist can also help them to find self-confidence and motivation for physical activities, social activities and may even help to find a job.

Focusing at potential risk factors of depression, we observed Zung score to be significantly correlated with NYHA functional class, type of physical activity, employment, and education. These results are consistent with a large-scale international study of more than $\mathbf{4 0 0 0}$ patients with different types of CHD, where the lower quality of life was associated with the lack of employment and worse NYHA functional class. ${ }^{2}$ In contrast to our study, Apers et al. reported an association of quality of life with older age. ${ }^{2}$ The same risk factors were associated with depression in our historical study. ${ }^{10}$ Similarly, Berghammer et al. reported NYHA, age, and gender as independent predictors of lower quality of life in general CHD population. ${ }^{3}$

The negative effect of unemployment on mental health (including depression, anxiety and well-being) is well documented. ${ }^{14,15}$ Our results suggest that the role of employment in the prevention of depression is increasing with the severity of CHD. The unemployed individuals had increased Zung depression score and this increase was the highest in unrepaired CHD patients, smaller but significant in repaired CHD patients, and lowest and non-significant in the control group. The reason of depression may be not only due to the financial aspects of being unemployed, but also due to the loss of self-confidence in patients primarily handicapped by the CHD.

Beyond the above mentioned risk factors, we observed an association of NT-proBNP with physical functioning in SF-36, in line with observations by Younge et al. ${ }^{16}$ This complements the established importance of NT-proBNP as a predictor of mortality in CHD. ${ }^{17-19}$
In spite of the relatively low depression rate in repaired CHD patients, which did not differ significantly from the control group, psychological assessment and detection of patients at higher risk of depression is needed. Kovacs et al. drew the attention to the under-treatment of anxiety disorders and depression in adults with CHD. ${ }^{20}$ The rate of patients with occasional suicidal thoughts was non-significantly higher in CHD patients (9.4\%) compared to controls $(4.7 \%)$. We need to discover the depressive patients in our daily practice actively and provide them with professional psychological or psychiatric help. The routine cardiologic check-up may not detect the depression. Our results show that depression in complex CHD patients is associated with higher NYHA class, unemployment, lower education and decreased physical activity. These risk factors can be partly helpful in the detection of patients at risk, who may be subsequently given a depression rating questionnaire. Our results show a good agreement of Zung score with SF-36 mental health ( $r=$ $-0.71)$ and vitality $(r=-0.69)$, suggesting that either may be used for depression screening. Severe depression was absent in patients with vitality or general health in SF-36 over 60 (Fig. 6).

Mental state and depression should be screened during outpatient visits. The use of questionnaires seems appropriate besides the personal discussion with patient. We consider filling the questionnaire during the outpatient visit much better compared to sending a letter, because patients have the possibility of clarifying questions they do not understand. Patients identified to be at risk of depression should be seen by psychologist or psychiatrist.

\section{Limitations of the study}

The interpretation of the comparison between repaired complex CHD patients in this study with unrepaired complex CHD patients from our historical study is limited by the fact that the studies were carried out 17 years apart. General treatment improvement, changes in population-wide quality of life and other factors might therefore influence difference between the two cohorts. 


\section{Conclusion}

In conclusion, adult patients after repair of complex cyanotic CHD in the studied cohort have a generally good quality of life, comparable to general population. The majority of our patients completed higher education, feel hopeful about the future, enjoy sexual activities, and declare to lead a full life. Patients with a repaired complex CHD report the influence of the CHD on their life as up to mild in $56 \%$. The CHD patients show no significant difference from the control group in depression rate and mental health as assessed by Zung score and SF-36, while their physical health is slightly reduced. This demonstrates that an early CHD repair is a highly successful treatment, given that unrepaired complex cyanotic CHD patients manifest higher rate of severe depression and worse NYHA class. These results give important perspective to cardiologists and parents who are deciding about continuation of pregnancy, after a complex CHD is diagnosed in the unborn child.

\section{Conflict of interest}

None declared.

\section{Funding}

This work was supported by Ministry of Health, Czech Republic - conceptual development of research organization, Nemocnice Na Homolce - NNH, Prague, Czech Republic, 00023884-IG160201 and University Hospital Motol, Prague, Czech Republic 00064203, IG 6004.

\section{Ethical statement}

Authors state that the research was conducted according to ethical standards.

\section{References}

1. Moons $P$, Bovijn $L$, Budts $W$, et al. Temporal trends in survival to adulthood among patients born with congenital heart disease from 1970 to 1992 in Belgium. Circulation 2010;122: 2264-2272.

2. Apers S, Kovacs AH, Luyckx K, et al. Quality of Life of Adults with Congenital Heart Disease in 15 Countries Evaluating Country-Specific Characteristics. J Am Coll Cardiol 2016;67: 2237-2245.

3. Berghammer M, Karlsson J, Ekman I, et al. Self-reported health status (EQ-5D) in adults with congenital heart disease. Int J Cardiol 2013;165:537-543.
4. Moons P, Van Deyk K, De Geest S, et al. Is the severity of congenital heart disease associated with the quality of life and perceived health of adult patients? Heart 2005;91:1193-1198.

5. Simko LC, Mcginnis KA. What Is the Perceived With Congenital Heart Disease and Does It Differ by Anomaly ? J Cardiovasc Nurs 2005;20:206-214.

6. Opic P, Roos-Hesselink JW, Cuypers JA, et al. Longitudinal development of psychopathology and subjective health status in CHD adults: a 30- to 43-year follow-up in a unique cohort. Cardiol Young 2016;26:547-555.

7. Moons P, Deyk KV, Bleser LD, et al. Quality of life and health status in adults with congenital heart disease: a direct comparison with healthy counterparts. Eur J Cardiovasc Prev Rehabil 2006;13:407-413.

8. Lane DA, Lip GYH, Millane TA. Quality of life in adults with congenital heart disease. Heart 2002;88:71-75.

9. Kourkoveli P, Rammos S, Parissis J. Depressive Symptoms in Patients with Congenital Heart Disease: Incidence and Prognostic Value of Self-Rating Depression Scales. Congenit Heart Dis 2015;10:240-247.

10. Popelova J, Slavik Z, Skovranek J. Are cyanosed adults with congenital cardiac malformations depressed? Cardiol Young 2001;11:379-384.

11. Zung WW. A self-rating depresion scale. Arch Gen Psychiatry 1965;12:63-70.

12. Gratz A, Hess J, Hager A. Self-estimated physical functioning poorly predicts actual exercise capacity in adolescents and adults with congenital heart disease. Eur Heart J 2009;30:497504.

13. Hager A, Hess J. Comparison of health related quality of life with cardiopulmonary exercise testing in adolescents and adults with congenital heart disease. Heart 2005;91:517-520.

14. Paul KI, Moser K. Unemployment impairs mental health: Metaanalyses. J Vocat Behav 2009;74:264-282.

15. Eslami B, Kovacs $\mathrm{AH}$, Moons $\mathrm{P}$, et al. Hopelessness among adults with congenital heart disease: Cause for despair or hope? Int J Cardiol 2017;230:64-69.

16. Younge JO, Eindhoven JA, Utens EW, et al. Association between $\mathrm{N}$-terminal pro-brain natriuretic peptide and quality of life in adult patients with congenital heart disease. Cardiol Young 2015;25:288-294.

17. Baggen VJM, Van Den Bosch AE, Eindhoven JA, et al. Prognostic Value of N-Terminal Pro-B-Type Natriuretic Peptide, Troponin-T, and Growth-Differentiation Factor 15 in Adult Congenital Heart Disease. Circulation 2017;135:264-279.

18. Popelová JR, Tomková M, Tomek J, et al. Usefulness of $\mathrm{N}$-Terminal Pro-Brain Natriuretic Peptide to Predict Mortality in Adults With Congenital Heart Disease. Am J Cardiol 2015;116:1425-1430.

19. Popelová JR, Tomková M, Tomek J. NT-proBNP predicts mortality in adults with transposition of the great arteries late after Mustard or Senning correction. Congenit Heart Dis 2017; 12:448-457.

20. A.H. Kovacs, A.S. Saidi, E.A. Kuhl, et al. Depression and anxiety in adult congenital heart disease: Predictors and prevalence. Int J Cardiol 2009;137:158-164. 